\title{
BMJ Global Health Engaging globally with how to achieve healthy societies: insights from India, Latin America and East and Southern Africa
}

\author{
Rene Loewenson (D) , ${ }^{1}$ Eugenio Villar (D) , ${ }^{2}$ Rama Baru (D) , ${ }^{3}$ Robert Marten (D) ${ }^{4}$
}

\begin{abstract}
To cite: Loewenson R, Villar E, Baru R, et al. Engaging globally with how to achieve healthy societies: insights from India, Latin America and East and Southern Africa. BMJ Global Health 2021;6:e005257. doi:10.1136/ bmjgh-2021-005257
\end{abstract}

Handling editor Seye Abimbola

Received 4 February 2021 Revised 31 March 2021 Accepted 1 April 2021

Check for updates

C) Author(s) (or their employer(s)) 2021. Re-use permitted under CC BY-NC. No commercial re-use. See rights and permissions. Published by BMJ.

${ }^{1}$ Training and Research Support Centre, Harare, Zimbabwe ${ }^{2}$ Facultad de Salud Pública y Administración, Universidad Peruana Cayetano Heredia, Lima, Peru

${ }^{3}$ Centre of Social Medicine and Community Health, Jawaharlal Nehru University, New Delhi, India

${ }^{4}$ The Alliance for Health Policy and Systems Research, WHO, Geneva, Switzerland

Correspondence to Dr Rene Loewenson; rene@tarsc.org

\section{ABSTRACT}

The way healthy societies are conceptualised shapes efforts to achieve them. This paper explores the features and drivers of frameworks for healthy societies that had wide or sustained policy influence post-1978 at global level and as purposively selected southern regions, in India, Latin America and East and Southern Africa. A thematic analysis of 150 online documents identified paradigms and themes. The findings were discussed with expertise from the regions covered to review and validate the findings.

Globally, comprehensive primary healthcare, whole-ofgovernment and rights-based approaches have focused on social determinants and social agency to improve health as a basis for development. Biomedical, selective and disease-focused technology-driven approaches have, however, generally dominated, positioning health improvements as a result of macroeconomic growth. Traditional approaches in the three southern regions previously mentioned integrated reciprocity and harmony with nature. They were suppressed by biomedical, allopathic models during colonialism and by postcolonial neoliberal economic reforms promoting selective, biomedical interventions for highest-burden diseases, with weak investment in public health. In all three regions, holistic, sociocultural models and claims over natural resources re-emerged. In the 2000s, economic, ecological, pandemic crises and social inequality have intensified alliances and demand to address global, commercial processes undermining healthy societies, with widening differences between 'planetary health', integrating ecosystems and collective interests, and the coercive controls and protectionism in technology-driven and biosecurity-driven approaches.

The trajectories point to a need for ideas and practice on healthy societies to tackle systemic determinants of inequities within and across countries, including to reclaim suppressed cultures; to build transdisciplinary, reflexive and participatory forms of knowledge that are embedded in and learn from action; and to invest in a more equitable circulation of ideas between regions in framing global ideas. Today's threats raise a critical moment of choice on which ideas dominate, not only for health but also for survival.
Summary box

- Two approaches have coexisted for centuries in global thinking on healthy societies: social determinants and rights-based approaches and biomedical/ pathogenic approaches, with global positions and policies presenting a dominant view that masks significant diversity in thinking about healthy societies in different regions.

- When biomedical approaches were imposed in India Latin America and East and Southern Africa, they undermined local cultural understandings of health, and in all three regions stimulated rights-based, social determinants and social medicine approaches to confront the alienation and health inequities generated by colonialism and globalisation.

- Advancing ideas into policy depends on growing social, scientific and policy networks and calls for spaces to debate contesting ideas, investment in a more equitable circulation of ideas between regions in framing global approaches, and transdisciplinary, reflexive and participatory ways of building knowledge that are embedded in and learn from action.

- In responding to threats posed to health by climate change, the damage to ecosystems and pandemics, how we think and act on healthy societies and how far the choices are understood and made beyond elites and states within society itself can lead us to significantly different futures.

\section{INTRODUCTION}

The way healthy societies are conceptualised plays a role in shaping efforts to achieve them. Within and across countries, different ideas coexist. Some assume dominance, whether by force or consent. In a constructivist analysis, that explores beyond the material reality the socially constructed nature of knowledge, the dominance or hegemony of particular ideas is a consequence of many factors. These include production relations and the use of material power to dominate others, but also the sociopolitical forces and relations, and the institutions, rules and procedures used 
to impose, negotiate, build convergence and maintain consent around particular ideas, and to suppress others. ${ }^{1}$ A social constructivist analysis brings the public into this analysis, arguing that hegemonic power is exercised when dominant ideas are embraced by society. It is thus not only the ideas advanced or imposed by socioeconomic elites and states that matter, but also those that are promoted by social actors and that exist in the public mindset. ${ }^{1}$

COVID-19 has exposed major shortcomings in our thinking about healthy societies and raises both demand and opportunity to reflect on, debate and challenge our thinking. We face a range of old and new challenges to building healthy societies. As pandemics, commercial practices, climate and ecosystems increasingly call for collective strategies across countries, what can we learn from the paradigms emerging from different regions globally?

To explore this, with the 1978 Alma Ata Declaration on Primary Health Care (PHC) as an entry point, we investigated the trajectory of frameworks for healthy societies that had wide or sustained policy influence. We covered those at global level, with its influences from Europe and the USA, and in three southern regions, India, Latin America and east and southern Africa (ESA). The southern regions were purposively selected as having significant populations, diverse cultures and histories that the authors (RL, EV and RB) had direct and sustained system and policy experience of. We analysed the features and drivers of the paradigms to generate insights on building shared frameworks for how to achieve healthy societies.

At global level and in the three aforementioned southern geopolitical areas-termed 'regions'—we identified dominant, persistent or influential paradigms post1970, noting earlier contributions to these ideas. We defined paradigms as systems of beliefs, ideas, values and actions that reflect thinking about the real world, and identified a healthy society as one that promotes health and does not wait for people to become ill. ${ }^{2}$

We included 150 English and Spanish documents obtained from online searches using key terms, regions and time frames and drew also on the authors' own experiences of the regions covered. A shared analytical framework was applied to document the goals, ideas and approaches within these paradigms and their drivers. A grounded thematic analysis was used to identify key themes. A structured meeting covering the review of the findings, the conclusions and the implications for policy and practice was held with experts to review and validate our findings. The reviewers were purposively selected from those identified from the source publications and those known to authors to collectively represent the different regions and global level; roles in academia, civil society, government, national, regional and global agencies; and health, rights, social determinants, system, political and social science and international relations disciplines. Further literature was sourced after the meeting to respond to feedback on methodological, paradigmatic, evidence and analytical issues.

Figure 1 shows the regions and paradigms included. Table 1 lists key policy events chronologically.

We recognise limitations: While the regions included cover significant populations, other important regions were excluded due to limitations of time, resources and language. The breadth of period and geographical scope implies a loss of detail. We did not explore policy implementation nor what affected this. The evidence is qualitative and intends to make no associations between paradigms and their health impact.

Notwithstanding these limitations, the regions reviewed featured compelling and influential discourses about healthy societies that can generate new insights on how to better engage with historically produced and contextdependent ideas of 'healthy societies', within and across countries globally.

\section{PARADIGMS FOR HEALTHY SOCIETIES}

This section summarises key features of the findings, presented separately in more detail. ${ }^{3}$ Box 1 summarises early ideas that contributed to paradigms covered.

\section{A pathogenic, biomedical paradigm}

A pathogenic paradigm that aimed to reduce disease as a basis for improved health flourished with advances in scientific knowledge and technology. It informed an optimistic expectation that disease could be eradicated by technology and modernisation, reinforced by the expansion of medical care in Europe.

In the three southern regions, its colonial application was less benevolent. Military, material, legal and scientific power was used to suppress local economies and cultures, undermining or criminalising traditional health systems even while appropriating their therapies. ${ }^{4-6}$ Colonial public health laws, like India's 1897 Epidemic Diseases Act, enabled authorities, sometimes supported by militaries, to forcefully segregate people and demolish 'infected places', with limited attention to remedying social conditions. ${ }^{5} 78$ Allopathic 'tropical medicine' was portrayed as a superior approach. ${ }^{9}$ After independence, many governments in ESA countries or Nehru's India sought to modernise through a 'catch-up' of Western models, expanding curative services and biomedical prevention to underserved populations. ${ }^{9-11}$ This yielded important gains in disease reduction. However, ignoring social realities and underlying causes also led to failures, such as in India's technologically driven 1955-1969 malaria eradication campaign. ${ }^{12}$ When combined with eugenic theories, it led to rights violations, such as in India's coercive sterilisation programme in the late 1900s. ${ }^{13}$

Although the 1978 PHC Declaration discussed later provided a contrasting approach, subsequent economic, oil and debt crises reinvigorated a biomedical focus. A 'Washington Consensus' of Organisation for Economic Co-operation and Development-country governments 


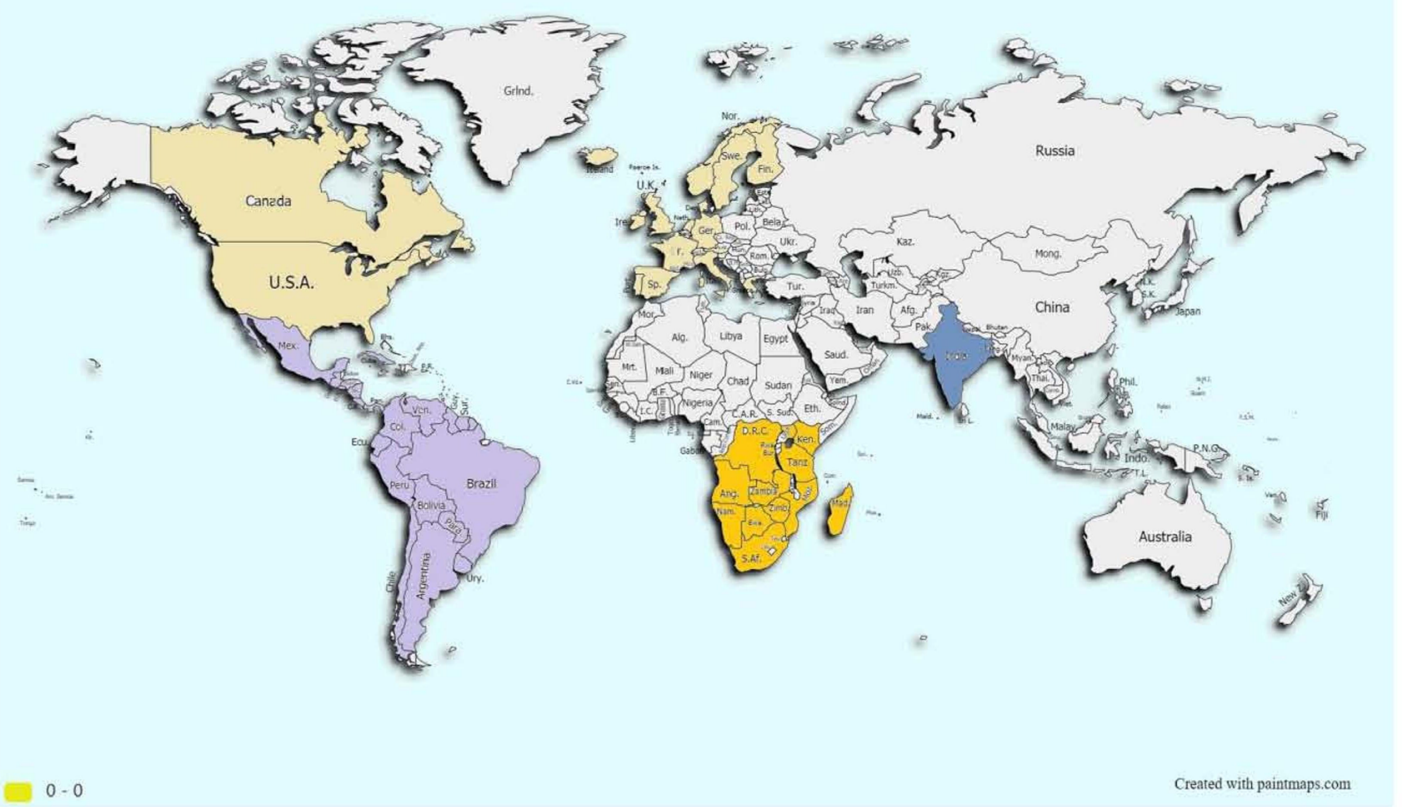

Created by authors with printmaps.com with permission

Key:

\begin{tabular}{|c|c|c|c|}
\hline $\begin{array}{c}\text { Europe, North } \\
\text { America and Global }\end{array}$ & Latin America & $\begin{array}{c}\text { East and Southern } \\
\text { Africa }\end{array}$ & India \\
\hline $\begin{array}{c}\text { The pathogenic, } \\
\text { biomedical paradigm }\end{array}$ & $\begin{array}{c}\text { The pathogenic, } \\
\text { biomedical paradigm }\end{array}$ & $\begin{array}{c}\text { Post-colonial } \\
\text { biomedical approaches }\end{array}$ & $\begin{array}{c}\text { 'Nehruvian' paradigm; } \\
\text { commodification of } \\
\text { health }\end{array}$ \\
\hline $\begin{array}{c}\text { Social medicine and a } \\
\text { social determinants } \\
\text { wellbeing paradigm }\end{array}$ & $\begin{array}{c}\text { The social medicine / } \\
\text { social determination } \\
\text { paradigm }\end{array}$ & $\begin{array}{c}\text { Social determinants } \\
\text { and resource } \\
\text { nationalism }\end{array}$ & $\begin{array}{c}\text { Gandhi's mind, body, } \\
\text { soul, community health } \\
\text { paradigm }\end{array}$ \\
\cline { 1 - 1 } $\begin{array}{c}\text { Universal rights and a } \\
\text { rights-based approach }\end{array}$ & $\begin{array}{c}\text { Buen vivir and } \\
\text { Planetary health as an } \\
\text { ecological wellbeing } \\
\text { paradigm }\end{array}$ & $\begin{array}{c}\text { Reciprocity in } \\
\text { traditional health } \\
\text { systems, ubuntu }\end{array}$ & Traditional paradigms \\
\hline $\begin{array}{c}\text { A biosecurity-focused } \\
\text { paradigm }\end{array}$ & $\begin{array}{c}\text { Colonial pathogenic } \\
\text { approaches }\end{array}$ & $\begin{array}{c}\text { Colonial pathogenic } \\
\text { approaches }\end{array}$ & $\begin{array}{c}\text { Colonial imposition of } \\
\text { allopathic medicine }\end{array}$ \\
\hline
\end{tabular}

Figure 1 Summary of the regions and broad paradigms covered within them.

and Bretton-Woods institutions responded to the crises with neoliberal reforms favouring free trade, deregulated markets and reduced social budgets. They argued that the wealth from macroeconomic growth would 'trickle down' and improve population health. The resulting social deficits and inequalities were seen as transitional and addressed by targeted social schemes and development aid. ${ }^{14}$ Within these neoliberal reforms, comprehensive PHC was seen to be infeasible. A 1979 Bellagio meeting sponsored by the Rockefeller Foundation and World Bank instead proposed 'selective PHC' as a set of technical, low-cost interventions, covering growth monitoring in children, oral rehydration, breast feeding and immunisations. ${ }^{12}$

Investment in public health was further weakened by the World Bank promotion of a 'cost-effective' package of biomedical services based on their unit cost for the disability-adjusted life years achieved. The World Bank also proposed a split of health systems into state-provided preventive services and primary care as public goods, with privately provided higher-level curative services. ${ }^{1115}$ While private philanthropic foundations have been involved in international health for over a century, the promotion of selective PHC and of private actors in health financing and systems opened a space for greater influence of the private sector in policy and governance and partnership with state and non-state organisations within countries and at the global level, including in global funds and alliances. ${ }^{16}$ While this was seen to bring new resources and technology to the sector, it also raised concerns about conflicts of interest between private, commercial interests, broader public health norms and interests and goals, 
Table 1 Timeline of selected major paradigm and policy events post-1978

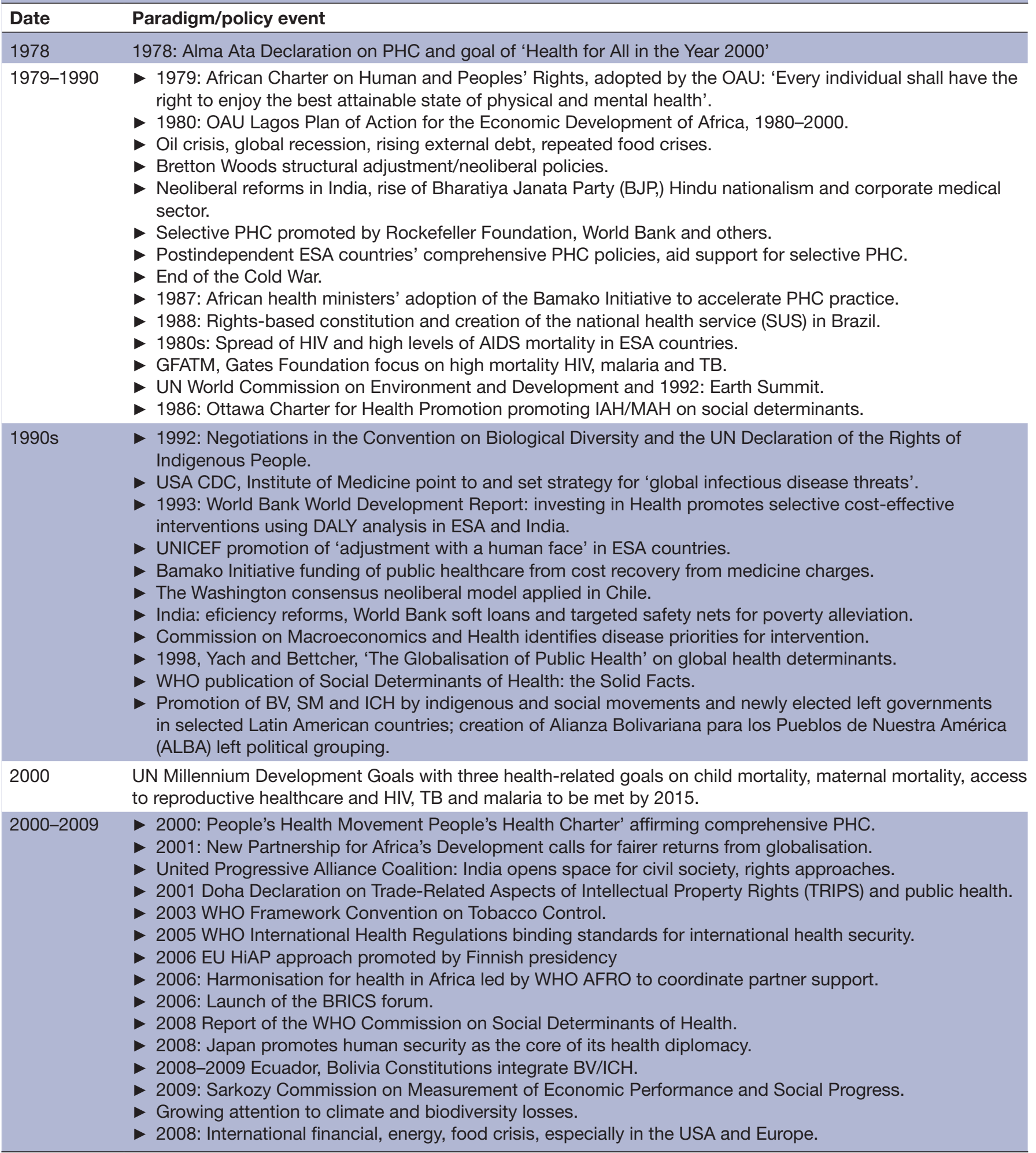




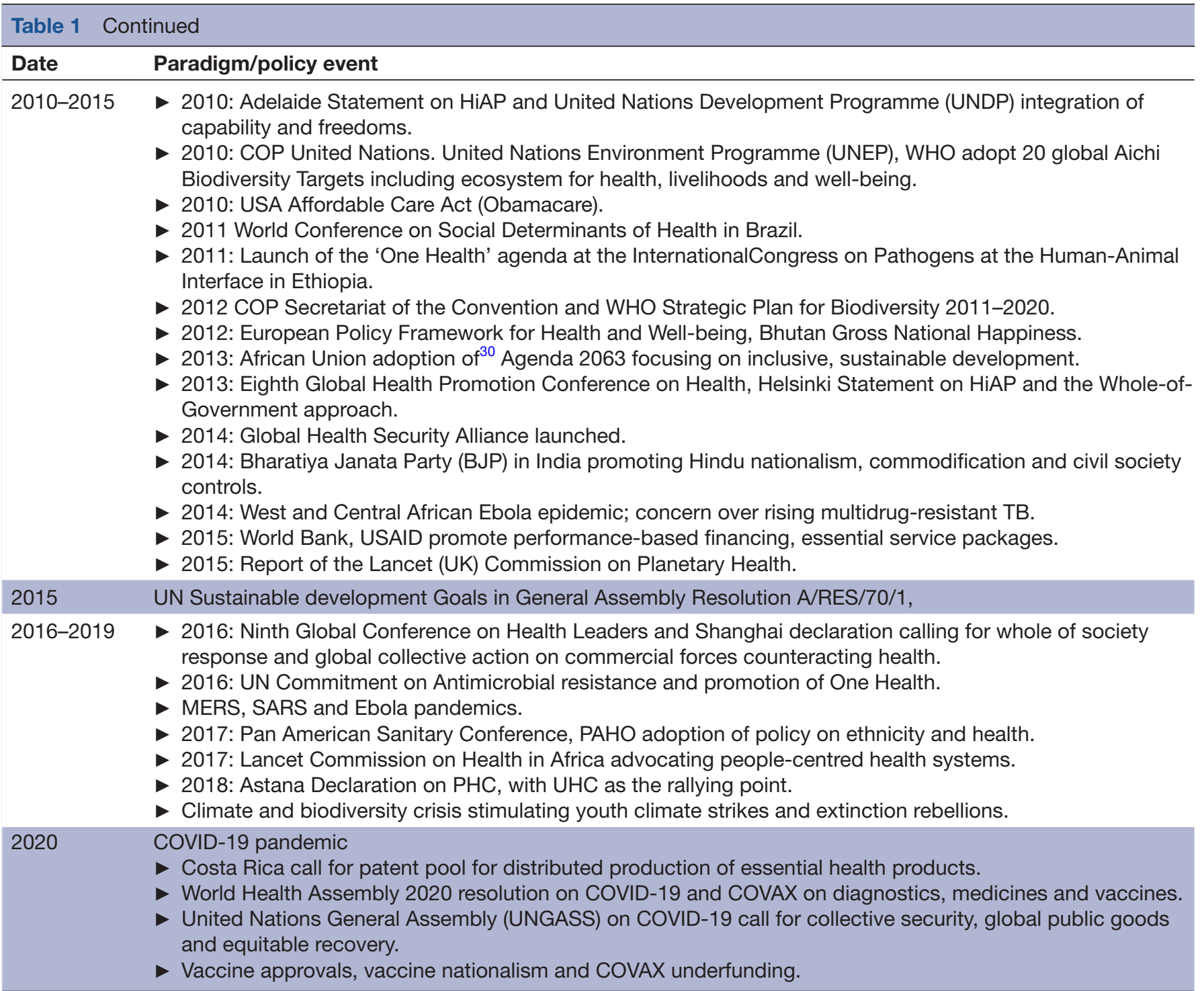

Authors from Loewenson et al..$^{3}$

AFRO, Regional Office for Africa; BRICS, Brazil, Russia, India, China and South Africa; BV, buen vivir; CDC, Centers for Disease Control and Prevention; COP, Conference of the Parties; DALY, disability-adjusted life year; EHP, essential health product; ESA, East and Southern Africa; EU, European Union; GFATM, Global Fund for AIDS, TB and Malaria; HiAP, Health in All Policies; IAH, intersectoral action for health; ICH, intercultural health; MERS, Middle East respiratory syndrome; OAU, Organisation of African Unity; PAHO, Pan American Health Organisation; PHC, Primary Health Care; SM, social medicine; SUS, Sistema Único de Saúde; TB, tuberculosis; UHC, universal health coverage; USAID, United States Agency for International Development.

including in relation to the focus and commercialisation of health services. ${ }^{16}$ In India, these measures strengthened the private medical industrial complex, while many ESA countries moved from comprehensive services to efficiency-led largely curative service packages. ${ }^{17-19}$ As a response to the rising poverty and resurgent infectious diseases from neoliberal reforms, UNICEF and others promoted targeted initiatives to reduce poverty as targeted, temporary philanthropy, not as a right. ${ }^{20}$

These developments triggered protest, especially from civil society. ${ }^{21}$ However, the paradigm shift was substantial: a 'healthy' neoliberal economy set the parameters within which measures for a healthy society should be achieved. It privileged individual responsibility and a limited role for the state, replacing universal health systems and social policy with commodified or targeted approaches. ${ }^{20}$ Globally, and with HIV surging in the late 1980 s, attention focused on biomedical management of high mortality diseases. This magnified vertical diseasefocused approaches and gave growing policy influence to newly created institutions like the Global Fund for AIDS, $\mathrm{TB}$ and Malaria and the Global Vaccine Alliance, and to private foundations like the Gates Foundation. ${ }^{14}$ These global partnerships helped to fill perceived gaps in system responses to high-mortality diseases. However, the significant technical and financial resources they directed to a selective, vertical disease approach was observed to skew agendas within countries and globally towards specific targeted biomedical outputs rather than systems or the deeper causes of diseases. ${ }^{16}$ 
Box 1 Paradigms prior to the 1978 Alma Ata Declaration with sustained or resurgent influence

Debates over the relative roles of microbes versus wider health determinants emerged and persisted for centuries historically, including between Hippocrates and Aristotle, BC, to Pasteur and Bechamp in the 1800s. A pathogenic paradigm informed quarantines to contain health risks and 'sanitary' reforms internationally, in Europe and in USA. ${ }^{12} 146171$ In contrast, Rudolf Virchow and Frederik Engels in the late 1800 s promoted social medicine (SM) to address the sociopolitical, structural causes of illness. ${ }^{37} 74$ Both pathogenic and SM approaches informed policies of the League of Nations Health Organisation, the precursor of the WHO. Extreme ideas also emerged. Eugenic theories attributing workers' risk in the 1918 influenza pandemic to 'inferior' genes rather than poor environments found conducive conditions during European fascism in the 1930s. ${ }^{71}$

The three southern regions had their own traditional approaches. Latin American Andean indigenous beliefs of buen vivir or sumaq kawsay in Quechua integrated harmony across human, spiritual and natural systems as a basis for well-being. ${ }^{75}$ In India, supernatural, moral, spiritual and material worlds were integrated in Ayurveda, Siddha, Unani and Tibb systems. ${ }^{76}$ Ubuntu ideas identified reciprocity in relationships between community members and ancestor spirits as a factor in well-being, informing practice in east and southern African countries. ${ }^{7778}$ These approaches reflected common features of community, collective interests, complementarity and reciprocity, positioning health as a consequence of harmony and equilibrium with nature and spiritual cosmic forces. They drew on and protected local biodiversity for their role in health, such as in the use of 1200 plants with therapeutic benefit in Kenya. ${ }^{49}$

The 2000 Millennium Development Goals (MDGs), in their focus on infant, under-5 year and maternal mortality, HIV, tuberculosis and malaria largely reflected this understanding of a healthy society being achieved through cost-effective interventions to reduce major causes of mortality. Having global goals did reassert state obligations for population health. ${ }^{22} 23$ However, the MDGs did not challenge the biomedical paradigm, and in their targeted approaches left many aspects of healthy societies poorly addressed, including those from commercial determinants associated with rising levels of chronic disease. ${ }^{18}$ The MDGs shifted the focus from what was technically and scientifically feasible for population health to what could be funded through bilateral aid and global institutions. ${ }^{23}{ }^{24}$ While contested and unresolved, the focus on universal health coverage in the later Sustainable Development Goals (SDGs) could enable a positive rights-based approach to access to healthcare. ${ }^{25}$ However, when framed in terms of what can feasibly be funded, it still focuses more on biomedical services than action on social determinants of health (SDHs) ${ }^{26}$

\section{A social medicine, social determinants paradigm}

In 1948, the Universal Declaration of Human Rights (UDHR) situated health within rights to living conditions, health and social services and social protection, a broad lens that was also reflected in the 1948 WHO constitution. ${ }^{27}$ Cold War political contestation between a
US focus on civil and political rights and a USSR focus on economic and social rights divided the UDHR framing into two separate covenants: the International Covenant on Civil and Political Rights and the 1966 International Covenant on Economic, Social, and Cultural Rights, with implicit tensions between individual and collective rights. ${ }^{27}$ Meanwhile sociopolitical movements in many southern regions were raising claims for socioeconomic justice, including those for their role in improving health.

In ESA countries, nationalist movements from the 1950 s built solidarity (and ubuntu) across countries in anticolonial struggles. They linked improved health to economic and political justice, socioeconomic rights and self-determination. Post-independence, this motivated a range of early redistributive socioeconomic policies to address health inequities, including comprehensive PHC. ${ }^{7}$ Comprehensive PHC was applied as a strategy to resolve historical inequities in health, to guide health development and to involve people in community health. PHC-related strategies promoted nutritious local food crops and community gardens, school health and gender parity in education, and expanded access to safe water and sanitation. ${ }^{7}$ Redistribution of land and greater domestic control over minerals, biodiversity and other resources, in a form of 'resource nationalism' was also seen as necessary for the economic inclusion needed to promote health equity and well-being and promoted in policy by countries, regional economic communities and the African Union. ${ }^{28-30}$ This has been a sustained focus into the 2000s, with the first goal of the African Union's Agenda 2063 development plan focusing on inclusive growth and sustainable development, through ensuring a high standard of living, food and social systems for a quality of life, sound health and well-being. ${ }^{30}$ Domestic efforts to apply comprehensive PHC also led ESA countries to engage globally in medicines access, migration of health workers, control of breastmilk substitutes, food security, debt cancellation and fair trade. ${ }^{29}$

In many Latin American countries, political activists adopted Virchow's SM approach noted in box 1. Rather than reducing health outcomes to individual risk factors, they viewed health as linked to social class and organised evidence and sociopolitical activism to confront the socioeconomic causes of ill health. ${ }^{31}$ Followers of Virchow who migrated to Latin America established SM courses. One of those trained was Salvador Allende, who was Chile's health minister and later president in 1970 who applied $\mathrm{SM}$ in socialist policies and in creating a tax-funded, universal National Health System. ${ }^{31}$ In Argentina, Ramón Carrillo and Juan Justo promoted investments in nutrition and living conditions to improve workers' health. Argentine-born physician Ernesto (Che) Guevara influenced the radical socioeconomic changes made after the 1959 Cuban Revolution, addressing the determinants of well-being and expanding universal primary care. ${ }^{32}$ Notwithstanding their positive health impact, when US-supported military dictatorships took power from the 1970s; they overturned these SM policies in favour of 
neoliberal market reforms, with the repression and exile of many SM proponents. ${ }^{31}$

In India, when state-led modernisation failed to deliver on social expectations, social movements advocated that '...the struggle for liberation (was) not just from alien rule but also from internal decay' (Kothari, p220). ${ }^{33}$ They stimulated grassroots community health projects that connected health with social justice and local democratic control. ${ }^{34}$ Mahatma Gandhi, the lawyer and anticolonial nationalist, was critical of earlier biomedical approaches. He proposed health promotion to achieve a balance between body, mind and spirit. He saw this as starting at village level, with healthy lifestyles, conditions and local herbal remedies promoted by primary health centres and community health workers. ${ }^{35}$ Many grassroots groups and issue-based coalitions adopted this paradigm in the 1970s. They learnt new concepts of a 'health worker' from the Chinese barefoot-doctor experience and promoted the idea of 'people's health in people's hands'. ${ }^{34} 36$

In the more multipolar world at the end of the Cold War, alliances widened around demands for more inclusive, long-term socioeconomic growth and fairer terms of trade and development finance, spearheaded by international institutions such as the Non-Aligned Movement, the Group of 77 and the UN Conference on Trade and Development. A 1974 UN General Assembly resolution called for a new international economic order. ${ }^{12}$ The view was that if the determinants of health are economic and social, the remedies must be too. ${ }^{37}$ WHO observed, 'people are beginning to ask for health and to regard it as a right' (Gostin et al, 2732). ${ }^{27}$ Halfdan Mahler, WHO Director General from 1973 to 1988, responded to these international pressures and local innovations, calling for new approaches (Chorev, p1). ${ }^{38}$ 'Health for All in the Year 2000' recognised the pressures for equity and justice, with many emergent ideas and innovations integrated in the 1978 Alma Ata Declaration's comprehensive PHC. ${ }^{12}$

Comprehensive PHC as a multidimensional, bottom-up and sociopolitical framing of health resonated with and reinforced these SM, social justice-driven, rights-based intentions. As noted earlier, PHC was central to postindependent ESA country health policies. ${ }^{71}$ Indian social movements advanced comprehensive PHC and rights-based approaches to health. ${ }^{39}$ The new governments replacing military regimes in Latin America in the 1990s implemented rights-based, redistributive, pro-poor social programmes and schemes that drew on SM and 'collective health' approaches. ${ }^{40}$

Internationally, the 1986 Ottawa Charter for Health Promotion built on the comprehensive PHC vision of healthy societies in promoting intersectoral action for health (IAH), recognising peace, socioeconomic conditions, sustainable ecosystems, social justice and equity as fundamental conditions for health. In contrast to the prior view that health improvements depended on rising aggregate wealth, the Charter posed health as a right and a resource for development. A 1993 World Conference on Human Rights brought socioeconomic and civil/political rights into one framework and identified collective agency as critical to realise such socioeconomic rights. ${ }^{41}$

A growing body of research evidence, including those from the 2008 WHO Commission on SDH, indicated how acting 'upstream' on SDH would tackle unjust inequalities in health. This motivated first IAH approaches, and then 'Health in All Policies', to integrate health into different sectoral policies, laws and measures. ${ }^{37} 4243$ 'Whole-ofGovernment' approaches went further to locate leadership for health outside the health sector, such as in the urban mayors of the European Healthy Cities Network. ${ }^{44}$

These approaches aimed largely at domestic intervention. However, new sociopolitical configurations also emerged around international-level challenges. Solidarity-based south-south cooperation grew through forums such as the Brazil, Russia, India, China and South Africa forum and in transnational social rights movements, such as the global People's Health Movement. ${ }^{29}$ These alliances engaged in and convened global processes on SDH. ${ }^{45} 46$ They challenged global barriers to public health. For example, an alliance of African, Indian and Brazilian diplomats and treatment activists successfully advanced the 2001 World Trade Oorganisation (WTO) Doha declaration on Trade-Related Aspects of Intellectual Property Rights (TRIPS) and Public Health to enable access to medicines, notwithstanding contestation by some high-income countries. ${ }^{22} 47$ By the end of the 1900 s, the context in which states constructed their national interests and ideas on how to promote healthy societies was changing, raising collective interests and opening space for non-state actors.

\section{Ideas for healthy societies within an intensifying neoliberal globalisation}

Rising global wealth in the 2000s, together with rising social inequality, economic insecurity and worsening living, working and community environments, challenged the idea that neoliberal economic growth guaranteed improved well-being. It signalled the limits of macroeconomic growth as a measure of progress, with a more multidimensional well-being, equity and intergenerational lens on development articulated, for example, in the 2009 Sarkozy Commission on Measurement of Economic Performance and Social Progress. ${ }^{12} 14$

In 1998, Yach and Bettcher identified the global diffusion of ideas, values, rights, knowledge, practices and products from transnational actors affecting health as global-level SDH. Rising food prices, a 2008 energy and financial crisis, conflict, population displacement, environmental and biodiversity degradation added growing evidence of such global determinants and their impacts, including on increased chronic disease, pandemics and social deprivation. ${ }^{14}$ Some countries and social movements called for global responsibilities to inform international cooperation and intervention. ${ }^{12}{ }^{37}$ In the early 2000s, various global measures were passed to promote cooperation and to limit market practices shown to be 
harmful to health, including those in the International Health Regulations (2005) and the Framework Convention on Tobacco Control (2003).

In Latin America, the negative local consequences of extractive transnational activities on environments, cultures and well-being motivated a renewed focus on the early 'buen vivir' (BV) ideas described in box 1, while the Latin American Social Medicine Association networked academic and sociopolitical actors in a sustained mechanism for SM influence, including those in global processes. ${ }^{48} \mathrm{BV}$ resonated with the aspirations for social justice, environmental protection, cultural diversity and the anti-imperialist perspectives of both indigenous people's organisations and left-wing governments, such as in Venezuela, Ecuador and Bolivia. ${ }^{49} 50$ The social policies informed by BV improved health and education outcomes and reduced poverty and social inequality. However, a dependence on foreign-owned extractive industries and deep integration in the global economy made BV-related economic policies more difficult to implement. ${ }^{51}$

An intercultural health (ICH) approach thus had wider application in Latin America. It too confronted the sociocultural alienation, inequities and racism from both colonialism and globalisation. A concept of 'plurinational' states legally recognised the multiethnic nature and rights of indigenous peoples, including the "right to be different' and to participate and coexist at all levels. ICH integrated indigenous health, farming, food and herbal knowledge and practices, and community power within comprehensive PHC. ${ }^{52} 5354$ In the 2000s, indigenous groups, technical experts and some governments worked with regional health organisations to operationalise ICH, while UNESCO, the International Labour Organization Convention 169 and the United Nations Declaration on Indigenous Peoples and their Right to Health widened its uptake. ${ }^{556}$

In ESA countries, where neoliberal reforms and a net outflow of resources from extractive activities diminished resources for social improvements, countries engaged in various south-south cooperation platforms and through African diplomatic unity to negotiate fairer returns from the global economy around trade, biodiversity, health worker migration among other issues, and for greater voice in global processes and governance, including to deliver on healthy societies nationally. ${ }^{518} 2957-59$

Many of these processes were state-led. However, the rise in social movements described earlier and the global impact of social movements on HIV, including in the 1994 establishment of Joint United Nations Programme on HIV/AIDS (UNAIDS), suggested that social activism using rights-based approaches could overcome powerful interests impeding health action by anchoring health development in claimant and duty bearer capacities and systems. This moved action from the optional realm of benevolence and aid into the mandatory realm of law, positioning people as active claimants of rights, rather than passive beneficiaries, and raising attention to the
Box 2 Debates over inequality in the Sustainable Development Goals (SDGs)

In the background work for the SDGs, one 'post-Millennium Development Goal' stream led by the UK advocated an international aid and technical development lens, while a second, with strong southern, environmental and equity voices, challenged the sociopolitical nature of development inequalities. Inequality was recognised by both streams, but there was a debate on whether it meant tackling the distributional inequality of power and wealth between social groups and countries, or focusing only on the exclusion of vulnerable and marginalised populations. This contestation between countries crystallised around whether and how to include a specific goal on inequality. ${ }^{80}$ When the World Bank introduced the concept of ending extreme poverty as the goal, it was contested for not addressing the growing concentration of wealth in the top decile. The concept was, however, advanced in a manner that masked political influence by shifting the debate to a technical committee focusing on how to 'frame' and measure the goals, locating inequality within a narrow set of individual factors that focused on vulnerability of individuals rather than inequalities in wealth. ${ }^{80}$

mechanisms and processes for exercising claims and holding duty bearers accountable. ${ }^{27} 60$

Within this global context, the 2015 SDGs integrated goals relevant to many SDHs. However, as shown in box 2 , the SDGs left unresolved debates on the global determination of inequalities in these SDHs. ${ }^{61}$

It was thus the later 2016 Global Conference of Health leaders' 'Shanghai Declaration' that took a more challenging global position on the sociopolitical determination of commercial and global determinants of healthy societies. The declaration raised the duties of different actors and sectors to address these determinants, calling for a whole of society engagement and global collective action to advance equity, and to address powerful commercial forces that work to counteract health. ${ }^{62}$

In the 2020s, climate change, the degradation of ecosystems; financial, energy and food crises; pandemics and antimicrobial resistance have given evidence of intensifying international determinants of healthy societies. These crises have highlighted links to production and consumption patterns and the extreme social inequality generated in the current global political economy, widening the differences between pathogenic and $\mathrm{SDH}-$ driven responses. ${ }^{54}$

\section{The emergence of planetary health}

Zoonotic pandemics, antimicrobial resistance and environmental challenges led in the 2000s to 'One Health' and 'Ecohealth' approaches that connected human, animal and environmental health, and to growing global dialogue on biodiversity and health. ${ }^{54616364}$

By the 2010s, the immediate and intergenerational climate and ecosystem threats to survival and growing evidence of policy alternatives gave impetus to a planetary health paradigm, intensifying demands to address global determinants of healthy ecosystems, with social protest, 
much youth-led, over environmental degradation and biodiversity losses. ${ }^{65}$

Planetary health builds on SDH approaches to integrate ecosystems essential for well-being and the actions needed to support them. Resonant with debates and traditional ideas noted in box 1 , it departed from a hierarchical cause-effect understanding of life and applied a social determinants paradigm to ecosystem issues at planetary scale, exploring the balance and interdependency between humans and nature. ${ }^{37}$ Consistent with SM approaches, it focused not only on risks and harms but also on the power relations and sociopolitical factors determining problems and responses from local to global level. Following the path of the 2016 Shanghai Declaration, proponents of the paradigm, such as in the 2015 Lancet Commission on Planetary Health, called for measures to tackle the vested interests and power imbalances undermining more sustainable and equitable patterns of consumption. ${ }^{64}$

\section{The escalation of a biosecurity focus}

While a healthy society was increasingly understood to demand a healthy planet, the pathogenic paradigm and its focus on technical interventions also obtained new momentum in a biosecurity paradigm, responding to recurrent health emergencies and perceived threats from biological weapons, biotechnology and bioterrorism that opened space to reconceptualise 'security' beyond military threats. ${ }^{14}$ Biosecurity, defined by WHO as the prevention, detection and response to infectious disease threats of international concern, became more pronounced in global policy-making in the 2000s. The September 11 terror attack in the USA possibly also gave greater impetus to its already increasing focus on health security. ${ }^{14}$ In 2014, a USA-supported Global Health Security Agenda was launched with 69 countries, international and non-state organisations, and corporations to respond to 'global health threats posed by infectious diseases'. ${ }^{1266}$

The COVID-19 pandemic in 2020 escalated this focus on biosecurity. On the one hand, some countries and communities have applied holistic, rights-based and SDHbased responses to COVID-19, catalysing debates about state obligations and global, collective responsibilities in the pandemic, including for key health technologies to be made available as global public goods. ${ }^{67}$ However, the more dominant response has been biosecurity-focused, largely through centrally led and sometimes coercive quarantining and control measures, often unresponsive to local conditions and communities. National protectionism has generated significant inequalities in access to essential health technologies, despite UN appeals for collective security ${ }^{67-69}$ While still evolving, the pandemic demonstrates the risks of a dominant technology-driven biosecurity focus, including in terms of socioeconomic inequality and insecurity, rights violations and social distrust, with the lowest income countries and communities most affected, and the ecosystem and deeper public health determinants of pandemics poorly addressed. ${ }^{67-69}$

\section{INSIGHTS FROM ACROSS DIVERSE IDEAS}

The findings highlight the influence of often coexisting and contrasting paradigms and approaches to healthy societies. While the trajectories reflect different cultures and political economy contexts, they suggest some shared insights for future engagement on healthy societies.

\section{Overcoming the consequences of imposed paradigms}

The evidence points to how an imposed pathogenic paradigm in the three southern regions undermined the local cultural understanding of health. The application of tropical medicine, the coercive segregation of local populations, the promotion of selective PHC as better aligned to neoliberal reforms and of allopathic medicine as a catch-up with Western development asserted a superiority of Western approaches and neoliberal policies, discounting, suppressing and even criminalising local systems. When combined with eugenic theories, a biomedical focus enabled racist or discriminatory discourses in health. In more recent years, significant technical and financial resources from private actors, international and global agencies reinforced a selective, vertical disease-focused approach.

In all three regions, precolonial ideas, outlined in box 1, re-emerged in new forms in anticolonial and antineoliberal movements, with ideas of $\mathrm{BV}$ and $\mathrm{ICH}$; Gandhi's mind, body, soul and community health paradigm in India; and the promotion of reciprocity and claims over natural resources articulated by ESA countries. An understanding of healthy societies has thus been linked to reclaiming cultures for dispossessed countries and people, a process that is ongoing, given the deep link between health, identity and justice. At the same time, such indigenous practice may be susceptible to manipulation, as, for example, has been observed in Hindu nationalism's use of Ayurveda to drive forms of ethnic exclusion and a discourse of obligation and security over that of rights and citizenship. ${ }^{70}$

A tropical medicine exceptionalism in how healthy societies are achieved in the south can be argued to have raised a barrier to the mutually useful exchange of learning between all regions on shared population health problems. It blocked for decades the wider uptake of useful positive learning from southern regions on local food and dietary practices; community health systems and community health workers; and on cultural and psychosocial integration in health, despite the relevance for multicultural, multiethnic societies in diverse regions. Ideas on healthy societies call for openness to 'reverse innovation', moving beyond the current dominance of institutions in high-income countries as a source of global ideas towards greater mutual horizontal exchange between and across regions.

\section{Engaging with structural determinants and social determination}

SM and SDH paradigms looked beyond disease and biomedical approaches to promote health and to act on 
the political determination of the conditions affecting health. However, a dominant argument that a growth in national wealth would achieve improvements in health subjugated health approaches to neoliberal measures, even when this intensified inequalities. In all regions, and often in a more radical form in the southern regions, there appears to be a growing understanding that any paradigm for healthy societies must engage with commercial determinants and the drivers from a neoliberal globalisation, with implications for redistributive, intergenerational and ecological justice.

Crisis within the global political economy would itself appear to generate momentum for this. Yet, crisis itself is not a guarantee of such momentum. After the 1978 adoption of comprehensive PHC, for example, rather than intensifying impetus for it, subsequent energy, financial and other crises were used to prioritise existing economic interests and to promote selective, biomedical, targeted interventions as being more feasible. The sustained drivers for a deeper engagement with global determinants of healthy societies may thus be more likely found in growing networks of social movements, forums and processes questioning the current global political economy and its markers of progress, and in the sharing of ideas on alternatives.

\section{Building a values-based, reflexive, context-dependent knowledge}

While positivist methods have significantly contributed to the understanding of health risks and to disease control, they have been less successful in building the multidisciplinary, reflexive and context-dependent knowledge needed for population health equity. Positivist methods consider that a single observable reality exists and that knowledge can be derived from this reality using impartial measurements that are free from contextual or subjective influence. In posing as values-neutral, positivist approaches can rather reflect dominant forces and ideologies, and negate the sociopolitical and cultural ways in which knowledge is generated. Approaches to healthy societies such as comprehensive PHC, BV, SM, the Gandhian paradigm, people's health in people's hands, ubuntu, resource nationalism and planetary health have, in contrast, all explicitly articulated the values and collective rights that inform their knowledge and action on improvements in well-being.

The multidimensional complexity and ethical policy choices required to build healthy societies increasingly demand embedded, transdisciplinary, reflexive and participatory approaches. This does not imply an unquestioning absorption of 'facts' asserted by the loudest voices, but rather systematic, organised processes to draw, analyse and validate evidence from lived experience of the many actors and levels involved in action on healthy societies, to build collective analysis and learning from action.

\section{Contestation as a fertile basis for change}

The trajectories described point to a 'battle for ideas' that has infused debates on how to advance healthy societies within and between countries and globally. This persistence of contestation in advancing paradigms for healthy societies needs more open recognition of both its underlying basis and its value, together with spaces for transparent engagement between proponents.

While global institutions have had significant influence on ideas for healthy societies, ideas have also flowed in other ways. A core-periphery model where ideas flow from highincome to low-income countries and regions, as applied in colonial modernisation, in aid-supported 'development' programmes and in neoliberal reforms appears obsolete, particularly in developing global health policy. Latin American ideas of ICH have been integrated in global declarations. Brazil and Chile influenced the ideas in the 2008 WHO Commission on SDH. India's community health experience with other country and local experiences influenced the thinking behind comprehensive PHC. ESA treatment activists and African diplomats established a precedence for public health in trade in the Doha declaration on TRIPS. Even ideas that flowed globally or north-south were reinterpreted locally, such as in the more politically radical view of SM in Latin America compared with its expression in Europe. ${ }^{71}$ A model of 'circulation' may better enhance understanding of and investment in the flows and the give and take of ideologies, policies and practices between different regions and networks in framing global ideas, ${ }^{72}$ and better suit the engagement between regions and processes for developing shared paradigms on healthy societies.

\section{CONCLUSION}

Beyond the hegemony imposed by military coercion, the findings suggest that ideational power has combined with material, political and institutional power to give some ideas on healthy societies greater dominance and policy influence. Ideas matter in producing change.

\section{Accepting a plurality of ideas}

There is not, nor has there been, a singular idea of healthy societies. We would suggest that neither should one be imposed. There has been significant effort to impose a singular, often Western-centric, hegemonic view on how to achieve healthy societies as superior to and more 'realistic', 'technically correct' and feasible than all other thinking. ${ }^{73}$ However, the notion of a singular idea is problematic for various reasons. First, while values may be shared, health is as much sociocultural and political as it is technical and material. Ideas about healthy societies are embedded in different histories and polities. A competition over which ideas become hegemonic reflects wider political and economic contestations. Second, ideas have changed over time, and while some paradigms may have dominated in discourse and policy internationally and within regions at points in time, others emerged or resurfaced in new spaces, bringing new policy and practice.

\section{Paradigm choices take us to significantly different futures}

We are more informed than ever of the challenges we face to healthy societies in our way of life, production 
and consumption patterns, environmental degradation and in the extreme social inequality generated in the current global political economy. By the 2020s, two profound global conditions with significant local and national impact provide a useful insight on the critical point we have reached for the way we think and act on these challenges.

The first, the COVID-19 pandemic, is providing evidence of the insufficiency of and inequity generated by reactive, nationally self-protective, singularly biomedical-focused approaches to health emergencies. Such approaches ignore and thus fail to remedy the deeper structural drivers of 'emergencies'. They discount the critical contribution of comprehensive, equity-and rights-based, participatory and ecological approaches, or of a reassertion of early ideas of reciprocity and collective interests in health.

A second challenge lies in climate change and extreme biodiversity losses, their existential threat to healthy societies and the proactive reciprocal, collective cooperation they call for. As these planetary threats become increasingly immediate and more widely understood, they are stimulating a new understanding of interdependency; new forms of international cooperation reflecting collective interests and new demands to tackle the vested interests and power imbalances that undermine sustainable and equitable patterns of production and consumption, reasserting early ideas of health demanding harmony with nature. ${ }^{64}$

Pandemics and climate change as manifestations of global crises show a potential of significantly different futures in the dominant thinking about and shaping of healthy societies. We live in a Gramscian moment of old and new ideas, where health threats are responded to by reviving old coercive public health approaches that leave many determinants unaddressed, even while new frameworks for global cooperation and collective responsibilities are advocated.

At this critical moment of choice, the social constructivist analysis suggests that we look not only to ideas advanced by elites and states for what assumes dominance, but also to those promoted by social actors. A key driver of healthy societies may thus be when sufficient people in communities, countries, regions and global institutions converge in seeing an unhealthy status quo as no longer acceptable; when we have generated the space and processes to fairly share and build ideas that benefit, are understood and embraced by the wider public; and when we have the confidence and assert the collective power to produce change.

Twitter Robert Marten @martenrobert

Acknowledgements The authors had a rich and informative (remote) meeting with the reviewers of the paper and thank them for their review feedback and perspectives. The reviewers were Professor Ghanshyam Shah, Dr Moeketsi Modisenyane, Dr Carlos Dora, Dr Oscar Feo, Dr Sharmila Mhatre and Professor Kelley Lee. Thanks to Sonam Yangchen and Solip Ha for formatting of references. This work was supported by the Alliance for Health Policy and Systems Research. The Alliance is able to conduct its work thanks to the commitment and support from a variety of funders. These include our long-term core contributors from national governments and international institutions, as well as designated funding for specific projects within our current priorities. For the full list of Alliance donors, please visit https://www.who.int/alliance-hpsr/partners/en/.

Contributors RL prepared the analytical framework used in the work with review input from RM, EV and RB. RL prepared background findings for the global level with review inputs from RM, and the background inputs on Africa. EV prepared background findings for the Latin American inputs and RB for the inputs from India. $\mathrm{RL}$ synthesised the findings and prepared the draft of the full paper, discussion and conclusions for review and input from EV, RB and RM. All authors made text input to iterative drafts and provided reference materials. RL coordinated the inputs and revisions and edited the final manuscript that all authors reviewed and signed off on.

Funding Funding for this paper was received from the Alliance for Health Policy and Systems Research, WHO (grant 202563639).

Map disclaimer The depiction of boundaries on the map(s) in this article does not imply the expression of any opinion whatsoever on the part of BMJ (or any member of its group) concerning the legal status of any country, territory, jurisdiction or area or of its authorities. The maps are provided without any warranty of any kind, either express or implied.

Competing interests None declared.

Patient and public involvement Patients and/or the public were not involved in the design, conduct, reporting or dissemination plans of this research.

Patient consent for publication Not required.

Provenance and peer review Not commissioned; externally peer reviewed.

Data availability statement All data relevant to the study are included in the article.

Open access This is an open access article distributed in accordance with the Creative Commons Attribution Non Commercial (CC BY-NC 4.0) license, which permits others to distribute, remix, adapt, build upon this work non-commercially, and license their derivative works on different terms, provided the original work is properly cited, appropriate credit is given, any changes made indicated, and the use is non-commercial. See: http://creativecommons.org/licenses/by-nc/4.0/.

\section{ORCID iDs}

Rene Loewenson http://orcid.org/0000-0002-9928-540X

Eugenio Villar http://orcid.org/0000-0003-0531-487X

Rama Baru http://orcid.org/0000-0002-0131-4242

Robert Marten http://orcid.org/0000-0002-2416-2309

\section{REFERENCES}

1 Schmidt B. Hegemony:A conceptual and theoretical analysis. DOC Research Institute, 2018. Available: https://doc-research.org/2018/ 08/hegemony-conceptual-theoretical-analysis/ [Accessed 7 Dec 2020]

2 Afifi AA, Breslow L. The maturing paradigm of public health. Annu Rev Public Health 1994;15:223-35.

3 Loewenson R, Villar E, Baru R. Achieving healthy societies - ideas and learning from diverse regions for shared futures. Training and Research Support Centre, 2020. Available: https://www.tarsc.org/ publications/documents/Healthy\%20societies\%20paper\%202020\% 20final.pdf [Accessed 7 Dec 2020].

4 Maldonado R. Interculturalidad Y políticas públicas en El MARCO del Buen Vivir. Quito: Ministerio de Salud Pública del Ecuador. Salud Interculturalidad y Derechos 2010.

5 Ichoku HE, Mooney G, Ataguba JE-O. Africanizing the social determinants of health: embedded structural inequalities and current health outcomes in sub-Saharan Africa. Int $J$ Health Serv 2013;43:745-59.

6 Kumar D, Basu RS. Medical encounters in British India. New Delhi: Oxford University Press, 2013.

7 Chatora R, Tumusime P. Primary health care: a review of its implementation in sub-Saharan Africa. Prim Health Care Res Dev 2004;5:296-306.

8 Mushtaq MU. Public health in British India: a brief account of the history of medical services and disease prevention in colonial India. Indian J Community Med 2009;34:6-14.

9 Baru R. Private health care in India: social characteristics and trends. New Delhi: Sage Publications, 1998. 
10 Banerji D. Health and family planning services in India. New Delhi: Lok Paksh, 1985.

11 Streefland P. Public health care under pressure in sub-Saharan Africa. Health Policy 2005;71:375-82.

12 Brown TM, Cueto M, Fee E. The World Health Organization and the transition from "international" to "global" public health. Am J Public Health 2006;96:62-72.

13 Rao M, Sexton S. Malthus and markets: gender and health in neoliberal times. Delhi: Sage publications, 2010.

14 Fidler DP. After the revolution: global health politics in a time of economic crisis and threatening future trends, articles by Maurer faculty 145, 2009. Available: https://www.repository.law.indiana.edu/ facpub/145 [Accessed 15 Oct 2020].

15 . World Bank. Investing in health. world development report. Washington DC: World Bank, 1993.

16 Rushton S, Williams OD. Partnerships and foundations in global health governance. UK: Palgrave Macmillan, 2011: 1-302.

17 World Health Organisation (WHO) AFRO. Review of primary health care in the African region. Brazzaville: WHO AFRO, 2008.

18 Regional Network for Equity in Health in East and Southern Africa (EQUINET). Regional equity Watch- assessing progress towards equity in health. Harare: EQUINET, 2012.

19 Baru R. Unravelling the 'social' in social determinants and health. In: Mehdi A, Rajan I, eds. Health of the nation. Oxford: Oxford University Press, 2018.

20 Mkandawire T. Targeting and universalism in poverty reduction. UNRISD social policy and development programme paper 23. Geneva: UNRISD, 2005

21 Kapilashrami A, Baru R. Global health governance and commercialisation of public health in India: actors, institutions and the dialects of global and local. UK: Routledge, 2019.

22 Brandt AM. How AIDS invented global health. N Engl J Med 2013;368:2149-52.

23 Marten R. How states exerted power to create the millennium development goals and how this shaped the global health agenda: lessons for the sustainable development goals and the future of global health. Global Public Health 2018;14:1-16.

24 Buse K, Hawkes S. Health in the sustainable development goals: ready for a paradigm shift? Global Health 2015;11:13

25 Ooms G, Latif LA, Waris A, et al. Is universal health coverage the practical expression of the right to health care? BMC Int Health Hum Rights 2014;14:3.

26 Clark J. Medicalization of global health 4: the universal health coverage campaign and the medicalization of global health. Glob Health Action 2014;7:24004.

27 Gostin LO, Meier BM, Thomas R, et al. 70 years of human rights in global health: drawing on a contentious past to secure a hopeful future. Lancet 2019;392:2731-5.

28 Youde J. Why look East? Zimbabwean foreign policy and China. Afr Today 2007;53:2-19.

29 Loewenson R, Modisenyane M, Pearcey M. African perspectives in global health diplomacy. Journal of health diplomacy 2014;1:1-20 https://tinyurl.com/yxdzb5va

30 African Union (AU). Agenda 2063: the Africa we want. Addis Ababa: AU, 2015. https://au.int/sites/default/files/documents/36204-docagenda2063_popular_version_en.pdf

31 Waitzkin H, Iriart C, Estrada A. Social medicine then and now: lessons from Latin America. American Journal of Public Health 2011;10:1592-601.

32 Quijano G. Papel de Fidel Castro en Los determinantes sociales de la salud en Cuba. Revista Cubana de medicina militar 2018;47:1-11.

33 Kothari R. Party and state in our times: the rise of non-party political formations. Alternatives 1984;9:541-64.

34 Shukla A, Phadke A. Health movement in India. Health action 1999;12:6-9.

35 lyengar S. Health care: the Gandhian way. 13th HM Patel memorial lecture, Karamsad, Anand, Gujarat, 2017. Available: http://www. charutarhealth.org/sites/default/files/13thhm_patel_memorial_ lecture text new 0.pdf [Accessed 25 Sep 2020].

36 Gill K. A primary evaluation of service delivery under the National rural health mission (NRHM): findings from a study in Andhra Pradesh, Uttar Pradesh, Bihar and Rajasthan. Working papers ID: eSocialSciences 2006.

37 De Angulo J, Losada L. Health paradigm shifts in the 20th century. Christian J for global health 2014;2:49-58 https://journal.cjgh.org/ index.php/cjgh/article/view/37/182

38 Chorev N. The world Health organization between North and South. Ithaca: Cornell University Press, 2012.

39 . National Human Rights Commission (NHRC).. Women's right to health. New Delhi: NHRC, 2006.
40 Nunes E. Paradigmas de la salud colectiva.. Ciencia e saude coletiva 2015;20:1.

41 Kenyon KH, Forman L, Brolan CE. Deepening the relationship between human rights and the social determinants of health: a focus on Indivisibility and power. Health Hum Rights 2018;20:1-10.

42 Howard R, Gunther S. Health in all policies: an EU literature review 2006 - 2011 and interview with key stakeholders. Brussels: EU, 2012.

43 Rasanathan K, Bennett S, Atkins V, et al. Governing multisectoral action for health in low- and middle-income countries. PLoS Med 2017;14:e1002285

44 Euro WHO. Healthy cities-Promoting health and equity - evidence for local policy and practice. Copenhagen: WHO Euro, 2014.

45 Padilha A. Brazil calls for PACT on social factors to improve health. Bull World Health Organ 2011:89:714-5.

46 Russo G, Shankland A. Brazil's engagement in health co-operation: what can it contribute to the global health debate? Health Policy Plan 2014;29:266-70.

47 Nunn A, Dickman S, Nattrass N, et al. The impacts of AIDS movements on the policy responses to HIV/AIDS in Brazil and South Africa: a comparative analysis. Glob Public Health 2012;7:1031-44.

48 REDSACOL-ALAMES. Boletin informativo No. 6. Caracas: REDSACOL-ALAMES, 2017.

49 Rodriguez A. UNASUR: Una Estrategia integral: América Latina en Movimiento Quito: América Latina en Movimiento 2013.

50 Hidalgo-Capitán AL, Cubillo-Guevara AP. Deconstrucción y genealogía del "buen vivir" latinoamericano. El (trino) "buen vivir" y sus diversos manantiales intelectuales. International development policy | Revue internationale de politique de développement 2017;9.

51 Comisión Económica para América Latina (CEPAL). Pobreza, desigualdad Y sistemas de protección social en América Latina, avances $Y$ desafíos. Santiago: CEPAL, 2015.

52 Aguirre B. Programas de salud en La situación intercultural. Ediciones especiales del Instituto indigenista interamericano 1955:23.

53 Salaverry O. Simposio de interculturalidad en salud. Revista Peruana de medicina experimental y salud publica 2010;27:80-9.

54 Roger F, Caron A, Morand S, et al. One health and EcoHealth: the same wine in different bottles? Infect Ecol Epidemiol 2016;6:30978.

55 Pan American Health Organisation (PAHO), WHO. Policy on ethnicity and health. CSP 29/7, Rev1. Washington, DC: PAHO, 2017.

$56 \mathrm{PAHO}, \mathrm{WHO}$. Health in the Americas: pathway to sustainable health. Washington, DC: PAHO, WHO, 2017.

57 Vearey J, Luginaah I, Magitta N. Urban health in Africa: a critical global public health priority. BMC Public Health 2019;19:340.

58 Harmer A, Buse K. The BRICS - a paradigm shift in global health? Contemporary politics 2014;20:127-45.

59 Gottschalk K. Explainer: the Non-Aligned movement in the 21st century. The conversation, 2016. Available: https://theconversation. com/explainer-the-non-aligned-movement-in-the-21st-century66057 [Accessed 25 Sep 2020].

60 OHCHR WHO. A human rights-based approach to health. Geneva: WHO Department of Ethics, Equity, Trade and Human Rights, 2009.

61 Ridgway E, Baker P, Woods J, et al. Historical developments and paradigm shifts in public health nutrition science, guidance and policy actions: a narrative review. Nutrients 2019;11:531.

62 WHO. Shanghai Declaration on promoting health in the 2030 agenda for sustainable development. 9th global conference on health promotion. Shanghai. 21-24, 2016. Available: https://www.who.int/ healthpromotion/conferences/9gchp/shanghai-declaration.pdf?ua $=1$ [Accessed 25 Sep 2020].

63 Gebreyes WA, Dupouy-Camet J, Newport MJ, et al. The global one health paradigm: challenges and opportunities for tackling infectious diseases at the human, animal, and environment interface in lowresource settings. PLoS Negl Trop Dis 2014;8:e3257.

64 Whitmee S, Haines A, Beyrer C, et al. Safeguarding human health in the Anthropocene epoch: report of the Rockefeller Foundation-Lancet Commission on planetary health. Lancet 2015;386:1973-2028.

65 Mersmann F, Wehnert T, Gopel M. Shifting paradigms unpacking transformation for climate action. Berlin: Wuppertal Institute for Climate, Environment and Energy $\mathrm{GmbH}, 2014$.

66 Global Health Security Agenda. A partnership against global health threats, 2020. Available: https://ghsagenda.org/ [Accessed 5 Oct 2020].

67 Loewenson R, Accoe K, Bajpai N, et al. Reclaiming comprehensive public health. BMJ Glob Health 2020;5:e003886.

68 Paul E, Brown GW, Ridde V. COVID-19: time for paradigm shift in the nexus between local, National and global health. BMJ Glob Health 2020;5:e002622. 
69 Wallace R, Liebman A, Chaves LF. COVID-19 and circuits of capital. Monthly review 2020;72:1-3.

70 Gudavarthy A, Vijay G. Social policy and political mobilisation in India: producing hierarchical fraternities and polarized differences. Development and change 2020;51:463-84.

71 Carter ED. Social medicine and international expert networks in Latin America, 1930-1945. Glob Public Health 2019;14:791-802.

72 Birn AE. The national-international nexus in public health: Uruguay and the circulation of child health and welfare policies, 1890-1940. História, ciências, Saúde-Manguinhos 2006;13:675-708.

73 Escobar A. Pluriversal politics: the real and the possible. Durham: Duke University Press, 2020.

74 Giovannini E, Hall J, Morrone A. A framework to measure the progress of societies. Revue d'économie politique 2011;121:93-118.
75 Monteverde S. Los Incas Y La fiesta de la Sitúa. Chungara revista de antropología chilena 2011;43:243-56.

76 Arnold D. Dietetics, mimesis and alterity: Food in Asian medical traditions and East-West exchanges. In: Kumar D, Basu R, eds. Medical encounters in British India. New Delhi: Oxford University Press, 2013: 80-97.

77 Prinsloo ED. A comparison between medicine from an African (Ubuntu) and Western philosophy. Curationis 2001;24:58-65.

78 Lebese RT. Ubuntu in health care: setting the tone for an interdisciplinary African epistemology. J AIDS Clin Res 2013;4:9.

79 Gakuya D, Okumu MO, Kiama SG. Traditional medicine in Kenya: past and current status, challenges, and the way forward. Scientific African 2020;8:e00360.

80 Fukuda-Parr S. Keeping out extreme inequality from the SDG agenda - the politics of indicators. Global policy 2019;10:51. 